\title{
UASB treatment of chemical synthesis-based pharmaceutical wastewater containing rich organic sulfur compounds and sulfate and associated microbial characteristics
}

\author{
Weicheng $\mathrm{Li}^{\mathrm{a}}{ }^{\mathrm{a}}$, Qigui Niu ${ }^{\mathrm{b}}$, Hong Zhang ${ }^{\mathrm{a}}$, Zhe Tian ${ }^{\mathrm{a}}$, Yu Zhang ${ }^{\mathrm{a}}$, Yingxin Gao ${ }^{\mathrm{a}, *}$, Yu -You Li ${ }^{\mathrm{b}, *}$, \\ Osamu Nishimura ${ }^{\mathrm{b}}$, Min Yang ${ }^{\mathrm{a}}$

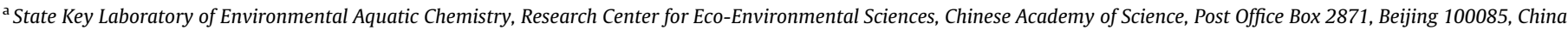 \\ ${ }^{\mathrm{b}}$ Department of Civil and Environmental Engineering, Graduate School of Engineering, Tohoku University, 6-6-06 Aza-Aoba, Aramaki, Aoba-ku, Sendai, Miyagi 980-8579, Japan
}

\section{H I G H L I G H T S}

- Successful application of UASB in treatment of rich organic S-bearing wastewater.

- Sulfate in effluent was higher than influent at $\mathrm{COD} / \mathrm{SO}_{4}^{2-}$ ratio of 8 and 5.

- Conversely, sulfate in influent was higher than effluent at $\mathrm{COD} / \mathrm{SO}_{4}^{2-}$ ratio of 1.5.

- Archaea and bacterial community varied greatly with altered OLR.

- Some species can be responsible for $\mathrm{S}$ release from organic sulfur compounds.

\section{A R T I C L E I N F O}

\section{Article history:}

Received 17 November 2013

Received in revised form 7 August 2014

Accepted 13 August 2014

Available online 6 September 2014

\section{Keywords:}

Chemical synthesis-pharmaceutical

wastewater

Organic sulfur compounds

UASB

$\mathrm{COD} / \mathrm{SO}_{4}{ }^{2-}$ ratio

Wastewater treatment

\begin{abstract}
A B S T R A C T
The feasibility of treating of chemical synthesis-based pharmaceutical wastewater containing rich organic sulfur compounds and sulfate using an upflow anaerobic sludge blanket (UASB) was investigated. The initial $\mathrm{COD} / \mathrm{SO}_{4}^{2-}$ ratio of 8 in the wastewater varied from 5 to 1.5 after adding sulfate. Of interest that under the condition of $\mathrm{COD} / \mathrm{SO}_{4}^{2-}$ at 8 and 5 , despite the simultaneous generation of sulfide and hydrogen sulfide, the sulfate concentration in the effluent was higher than in the influent. This is due to the sulfur release in the form of sulfate during the degradation of these organic sulfur compounds in this reactor. Conversely, at $\mathrm{COD} / \mathrm{SO}_{4}^{2-}$ of 1.5 , influent sulfate was higher than effluent sulfate due to reduction of more sulfates in the reactor. At $\mathrm{COD} / \mathrm{SO}_{4}^{2-}$ of 8 , for practical application, the optimum OLR was found to be $8 \mathrm{~kg}$ $\mathrm{COD} / \mathrm{m}^{3} / \mathrm{d}$, where a nearly $70 \%$ COD reduction occurred with biogas containing $63 \%$ methane. In this stage, the distribution of the archaea and bacterial community varied greatly with altered OLR (accompanied with prolonged operation time). Some species, such as Lysinibacillus sphaericus, Clostridium cellulovorans were expected to be partly responsible for $\mathrm{S}$ release from some organic sulfur compounds in the reactor. By increasing the sulfate loading at a $\mathrm{COD} / \mathrm{SO}_{4}^{2-}$ ratio up to 1.5 resulted in a light inhibition of methanogenesis due to the high sulfide concentration $\left(1212 \mathrm{SO}_{4}^{2-}-\mathrm{S} \mathrm{mg} / \mathrm{L}\right)$ with no obvious suppression of sulfidogenesis.
\end{abstract}

(c) 2014 Elsevier B.V. All rights reserved.

\section{Introduction}

Most pharmaceutical compounds are prepared by chemical synthesis, which involves a complex series of chemical reactions. During the production processes, a wide range of organic and inorganic constituents including raw materials, solvents, reaction

* Corresponding authors. Tel.: +86 10 62849149; fax: +86 1062923541 (Y. Gao). Tel.: +81 22 7957464; fax: +813737957465 (Y.-Y. Li).

E-mail addresses: gyx@rcees.ac.cn (Y. Gao), yyli@epl1.civil.tohoku.ac.jp (Y.-Y. Li). intermediates and products will be released into wastewater at high concentrations. The high chemical oxygen demand (COD) characteristics of the chemical synthesis-based pharmaceutical wastewaters make them potential candidates for anaerobic treatment. However, it is well known that many chemicals, especially aromatic pollutants originated from chemical synthesis such as sulfanilic acid and its derivatives are hardly anaerobically degraded [1]. In particular, some of these compounds may be inhibitory to activities of wastewater treatment microbes. For example, almost complete inhibition of methanogenesis occurred upon an 
anaerobic reactor receiving high concentration of terephalate up to $430 \mathrm{mg} / \mathrm{L}$ [2]. At the same time, high concentrations of ammonium or sulfate may exist in wastewater, which could inhibit the growth of methanogenic microbes $[3,4]$.

Under the presence of high concentrations of sulfate, the growth of sulfate reducing bacteria (SRB) could be stimulated to out-compete methane producing bacteria (MPB) for substrates $\left(\mathrm{H}_{2}\right.$ and acetate) [5]. Moreover, the SRB can convert sulfate into sulfide which could be toxic to MPB and decrease methane production [6]. Methanogenesis inhibition by $50 \%$ has been observed when $\mathrm{H}_{2} \mathrm{~S}$, the free soluble form of sulfide, was present in water with a concentration being over $50 \mathrm{mg} / \mathrm{L}[7,8]$. It has been concluded that a $\mathrm{COD} / \mathrm{S}$ ratio higher than 10 is desirable to prevent the inhibition of methane production $[9,10]$.

On the other hand, for the production of some pharmaceuticals, such as sulfonylureas, sulfur organic compounds like sulfonamides are also extensively used as raw materials, and thus end up in wastewater [11]. Up to now, most previous studies have focused on the degradation ability of these organic sulfur compounds under anaerobic conditions since many of them (such as xenobiotics) were regarded as resistance to anaerobic degradation [12]. For instance, a recent work demonstrated that sulfamerazine (an antibacterial agent) in pharmaceutical wastewater was found to be biodegradable and the threshold concentration of inhibition to methanogenesis was found to be as high as $90 \mathrm{mg} / \mathrm{L}$ in a UASB reactor [13]. Another example, linear alkylbenzene sulfonate (LAS) has historically been considered inaccessible to biodegradation under anaerobic condition [14]. However, there is growing evidence of the success of degradation of LAS in the presence of various electron donors recently [15]. Once degraded under anaerobic digestion, sulfur in these organic sulfur compounds will be readily released as sulfate and sulfide into water [16]. To date, many literatures just demonstrated that the sulfur discharged in the form of sulfate and sulfide from organic sulfur compounds was only used as a sulfur source during the anaerobic process [17]. However, little is known regarding the impacts of the release of sulfur from the organic sulfur compounds in wastewater on anaerobic digestion performance. The purpose of this work was to investigate the possibility of treating real pharmaceutical wastewater rich in organic sulfur compounds and sulfate using a UASB and to characterize the variation of archaeal and bacterial microbial community corresponding to process performance.

\section{Materials and methods}

\subsection{Experimental setup}

A schematic diagram of the experimental set up is illustrated in Fig. 1. The UASB reactor was made of plexiglass cylinder with an internal diameter of $100 \mathrm{~mm}$ and a working volume of $6 \mathrm{~L}$. The reactor has several sampling points at different heights and was water-jacketed to maintain a constant temperature at $37 \pm 1^{\circ} \mathrm{C}$. On top of the reactor was a gas-liquid-solid separator with an internal diameter of $150 \mathrm{~mm}$ and a height of $295 \mathrm{~mm}$. The effluent was collected in a container. The produced biogas was connected to a wet gas flow meter via a simple liquid displacement unit.

\subsection{Pharmaceutical wastewater characteristics}

Wastewater was provided by Fukang Pharmaceutical Company, Shandong Province, China. As shown in Table 1, this wastewater contained diverse chemicals including 1,3,5-tribromobenzene, 1-bromo-3-nitrobenzene, bromopropane, 3-aminophenol, 1-bromobutane and two organic sulfur compounds ( $p$-acetylsulfanilyl chloride and para-ester) (Sulfonated aromatic) and some unknown compounds, and was characterized with high concentrations of sulfate $(7995 \mathrm{mg} / \mathrm{L})$ and total sulfur (TS) $\left(1.70 \times 10^{4} \mathrm{SO}_{4}^{2-}-\mathrm{S} \mathrm{mg} /\right.$ L). Prior to this experiment, raw wastewater was diluted by tap water to give a COD of approximately $10,000 \mathrm{mg} / \mathrm{L}$. The COD/ $\mathrm{SO}_{4}^{2-}$ of raw wastewater was around 8 . To provide enough alkalinity, $15,000 \mathrm{mg} / \mathrm{L} \mathrm{NaHCO}_{3}$ was added to the influent of the UASB reactor.

\subsection{Experimental design}

The reactor was inoculated with $3 \mathrm{~L}$ mesophilic granular sludge from a full-scale UASB reactor treating food manufacturing wastewater in Shijiazhuang City, Hebei Province, China. The initial

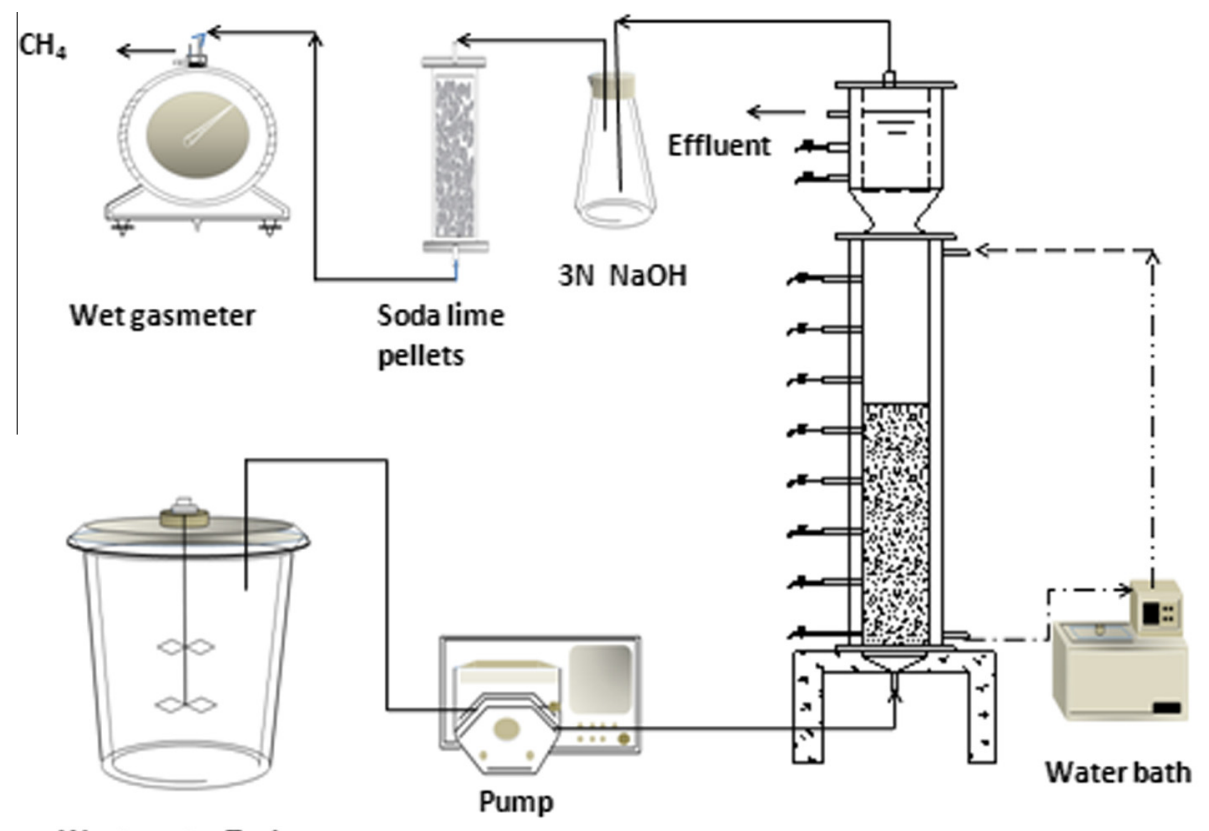

Wastewater Tank

Fig. 1. Schematic diagram of the UASB set-up. 
Table 1

Characteristics of the pharmaceutical industry wastewater.

\begin{tabular}{|c|c|c|c|}
\hline Name & Unit & Range & Average \\
\hline 1,3,5-Tribromobenzene & $\mathrm{mg} / \mathrm{L}$ & $1398-1508$ & 1453 \\
\hline 1-Bromo-3-nitrobenzene & $\mathrm{mg} / \mathrm{L}$ & 1664-1836 & 1750 \\
\hline 3-Aminophenol & $\mathrm{mg} / \mathrm{L}$ & $2217-2433$ & 2325 \\
\hline 1-Bromopropane & $\mathrm{mg} / \mathrm{L}$ & $2268-2490$ & 2379 \\
\hline 1-Bromobutane & $\mathrm{mg} / \mathrm{L}$ & $2385-2590$ & 2488 \\
\hline $\begin{array}{l}\text { p-Acetamidobenzene sulfonyl } \\
\text { chloride }\end{array}$ & $\mathrm{mg} / \mathrm{L}$ & $483-529$ & 502 \\
\hline Para-ester & $\mathrm{mg} / \mathrm{L}$ & $558-577$ & 568 \\
\hline $\mathrm{pH}$ & & $1.9-2.1$ & 2.0 \\
\hline COD & $\mathrm{mg} / \mathrm{L}$ & $\begin{array}{l}5.6 \times 10^{4}- \\
6.4 \times 10^{4}\end{array}$ & $6.0 \times 10^{4}$ \\
\hline Conductivity & $\mu \mathrm{s} / \mathrm{cm}$ & $76-80$ & 78 \\
\hline $\mathrm{NH}_{4}^{+}-\mathrm{N}$ & $\mathrm{mg} / \mathrm{L}$ & $80-116$ & 98 \\
\hline $\mathrm{SO}_{4}^{2-}$ & $\begin{array}{l}\mathrm{mg} \mathrm{S} / \mathrm{L} \\
\mathrm{mg} \mathrm{SO}_{4}^{2-} /\end{array}$ & $\begin{array}{l}2615-2715 \\
7845-8145\end{array}$ & $\begin{array}{l}2665 \\
7995\end{array}$ \\
\hline TS & $\begin{array}{l}\mathrm{mg} \mathrm{S} / \mathrm{L} \\
\mathrm{mg} \mathrm{SO}_{4}^{2-} / \\
\mathrm{L}\end{array}$ & $\begin{array}{l}5515-5815 \\
1.65 \times 10^{4}- \\
1.75 \times 10^{4}\end{array}$ & $\begin{array}{l}9561 \\
1.70 \times 10^{4}\end{array}$ \\
\hline Organic S & $\begin{array}{l}\mathrm{mg} \mathrm{S} / \mathrm{L} \\
\mathrm{mg} \mathrm{SO}_{4}^{2-} /\end{array}$ & $\begin{array}{l}2900-3100 \\
8700-9300\end{array}$ & $\begin{array}{l}3000 \\
9000\end{array}$ \\
\hline
\end{tabular}

sludge concentration of the reactor was $45 \mathrm{~g}$ VSS/L. Table 2 summarizes the operating conditions applied to the UASB in different experimental periods $(I-V)$ over a period of nearly 200 days. The COD and $\mathrm{pH}$ of the feed was kept at around $10,000 \mathrm{mg} / \mathrm{L}$ and 6.8 throughout the operation period. The organic loading rate (OLR) was increased from 1 to $24 \mathrm{~kg} \mathrm{COD} / \mathrm{m}^{3} /$ day in a stepwise fashion by reducing the HRT (hydraulic residence time) (Phase I). In Phase II, the OLR was returned to $8 \mathrm{~kg} \mathrm{COD} / \mathrm{m}^{3} /$ day to evaluate the recovering ability in treatment efficiency. After this, the $\mathrm{COD} / \mathrm{SO}_{4}^{2-}$ was changed to 5 and 1.5 respectively via adding $\mathrm{Na}_{2} \mathrm{SO}_{4}$ in order to test the $\mathrm{COD} / \mathrm{SO}_{4}^{2-}$ effect on the performance of the reactor (Phases III and IV). Finally, the $\mathrm{COD} / \mathrm{SO}_{4}^{2-}$ was reduced again to 8 in Phase V, which lasted for 26 days.

\subsection{Analytical methods}

The chemical oxygen demand (COD), pH, soluble sulfide, volatile fatty acids (VFA) and volatile suspended solids (VSS) were routinely determined during the operation using standard analytical procedures published by the American Public Health Association [18]. The sulfide concentration in the effluent was measured by the standard iodometric method, and sulfate was determined by ion chromatography (DIONEX, ICS-2100). TS (total sulfur) was determined by Elemental Analyzer (ELEMENTAR, VARIO ELIII).

Table 2

Operational conditions of the UASB reactor.

\begin{tabular}{lllcc}
\hline Period & Days & $\mathrm{COD} / \mathrm{SO}_{4}^{2-}$ & OLR $\left(\mathrm{kg} \mathrm{COD} / \mathrm{m}^{3} / \mathrm{d}\right)$ & HRT $(\mathrm{d})$ \\
\hline I & $1-20$ & 8 & 1 & 10.7 \\
& $21-30$ & & 2 & 5.3 \\
& $31-40$ & & 3 & 3.5 \\
& $41-50$ & & 4 & 2.6 \\
& $51-60$ & & 6 & 1.7 \\
& $61-70$ & & 8 & 1.3 \\
& $71-86$ & & 12 & 0.89 \\
& $87-100$ & & 24 & 0.67 \\
II & $101-120$ & & 8 & 0.45 \\
III & $121-140$ & 8 & 8 & 1.3 \\
IV & $141-154$ & 5 & 8 & 1.3 \\
V & $155-170$ & 1.5 & 8 & 1.3 \\
& $171-196$ & 8 & 1.3 \\
\hline
\end{tabular}

The organic $S$ in the feed and effluent was given by subtracting all of the inorganic sulfur species from the TS. The methane content was monitored by gas chromatography (GC 2010, SHIMADZU) equipped with a thermal conductivity detector (TCD) after biogas was washed with a $3 \mathrm{~N} \mathrm{NaOH}$ solution and passed through a column filled with soda lime pellets to remove $\mathrm{H}_{2} \mathrm{~S}$ and $\mathrm{CO}_{2}$. Aqueous $\mathrm{H}_{2} \mathrm{~S}$ was calculated based on the following equation [19]: $\mathrm{H}_{2} \mathrm{~S}$ fraction $=1 /\left(1+\left(K_{1} / 10^{-\mathrm{pH}}\right)\right)$, where $K_{1}$ is the first ionization constant of $\mathrm{H}_{2} \mathrm{~S} . \mathrm{H}_{2} \mathrm{~S}$ in the biogas was measured with hydrogen sulfide detecting tubes (Gastec, No. 4H). All the analytical estimates were made in duplicate and the average figures are presented.

\subsection{Cloning analysis of $16 S$ rDNA gene}

Biomass samples were collected on days 60 and 120 from the UASB for the analysis of microbial community structures. Biomass was harvested by centrifuging of the samples at $20,000 \times g$ for $10 \mathrm{~min}$, and the genomic DNA was extracted from the samples with an Ultra Clean Soil DNA Isolation Kit (MO-BIO). The amplification of $16 \mathrm{~S}$ rDNA was performed with the primers EUB 8F [20] and Univ1500R [21] for bacteria and A109F [22] and 1059R [23] for archaea. Thermal cycling of PCR consisted of $30 \mathrm{~s}$ denaturing at $94{ }^{\circ} \mathrm{C}, 40 \mathrm{~s}$ of annealing at $50^{\circ} \mathrm{C}$ and extracting at $72{ }^{\circ} \mathrm{C}$ for $1 \mathrm{~min}$ with 30 cycles for archaea and 23 cycles for bacteria. The PCR products were purified with Micro Spin ${ }^{\mathrm{TM}}$ S-400 HR (Amersham Pharmacia GE, USA). The purified DNA was cloned with the TOPO TA Cloning ${ }^{\circledR}$ Kit (Invitrogen, USA) and transformed into Escherichia coli DH5 ${ }_{\text {a }}$ competent cells. Cloned DNA fragments were obtained and spread on plates. After an incubation period of $24 \mathrm{~h}$ at $37{ }^{\circ} \mathrm{C}$, the white ones were randomly picked out and transferred to LB with another $6 \mathrm{~h}$ of continuous incubation. An insert check was performed using a vector of an M13 primer. The successful ones were used for sequencing. Similarity searches for the assembled sequences were performed using the NCBI Blast search program within the GenBank database (http://www.ncbi.nlm.nih.gov/ blast/).

\section{Results}

\subsection{Effect of OLR on treatment performance (Phases I and II)}

The treatment performance of the UASB is shown in Fig. 2. With an OLR below $8.0 \mathrm{~kg} \mathrm{COD} / \mathrm{m}^{3} / \mathrm{d}$ and an HRT above 1.3 day, the COD removal efficiency was around $69-78 \%$. Starting from day 71 , the COD removal efficiency dropped sharply to $58 \%$ at OLR of $12.0 \mathrm{~kg}$ $\mathrm{COD} / \mathrm{m}^{3} / \mathrm{d}$ at an HRT of 0.83 day and decreased further to $36 \%$ at around $24.0 \mathrm{~kg} \mathrm{COD} / \mathrm{m}^{3} / \mathrm{d}$ on day 120 at an HRT of 0.45 day (Fig. 2a and b). In parallel, an obvious increase of VFA in the effluent was accompanied with HRT reduction and OLR increase (Fig. 2c). The VFA level was approximately $220 \mathrm{mg} / \mathrm{L}$ at an OLR of $8 \mathrm{~kg} \mathrm{COD} / \mathrm{m}^{3} / \mathrm{d}$, in comparison to $450 \mathrm{mg} / \mathrm{L}$ at $12 \mathrm{~kg} \mathrm{COD} / \mathrm{L} / \mathrm{d}$ and $850 \mathrm{mg} / \mathrm{L}$ at the highest OLR. The increase of VFA was accompanied by a decrease in $\mathrm{pH}$ (from 8.5 to 7.1, Fig. 2d). Similarly, accompanying the increase in the VFA level during HRT reduction, methane content in the biogas tended to decrease (Fig. 2f). The methane content was $66 \%$ or higher at an OLD below $16 \mathrm{~kg} \mathrm{COD} / \mathrm{L} / \mathrm{d}$, but dropped to $48 \%$ at an OLD of $24 \mathrm{~kg} C O D / L / d$, showing that the reactor was in serious acidification condition, which was in accordance with the sharp increase of VFA and the changes in methane yield rate. After resetting the OLR to $8 \mathrm{~kg} C O D / \mathrm{m}^{3} / \mathrm{d}$ by increasing the HRT to 1.3 days (Phase II), the COD removal efficiency quickly recovered to over $60 \%$, together with recoveries in $\mathrm{pH}$, VFA and methane content, showing the resilience of the UASB system. Thus, in terms of practical application, an OLR of $8 \mathrm{~kg} \mathrm{COD} / \mathrm{m}^{3} / \mathrm{d}$ will be suitable. 

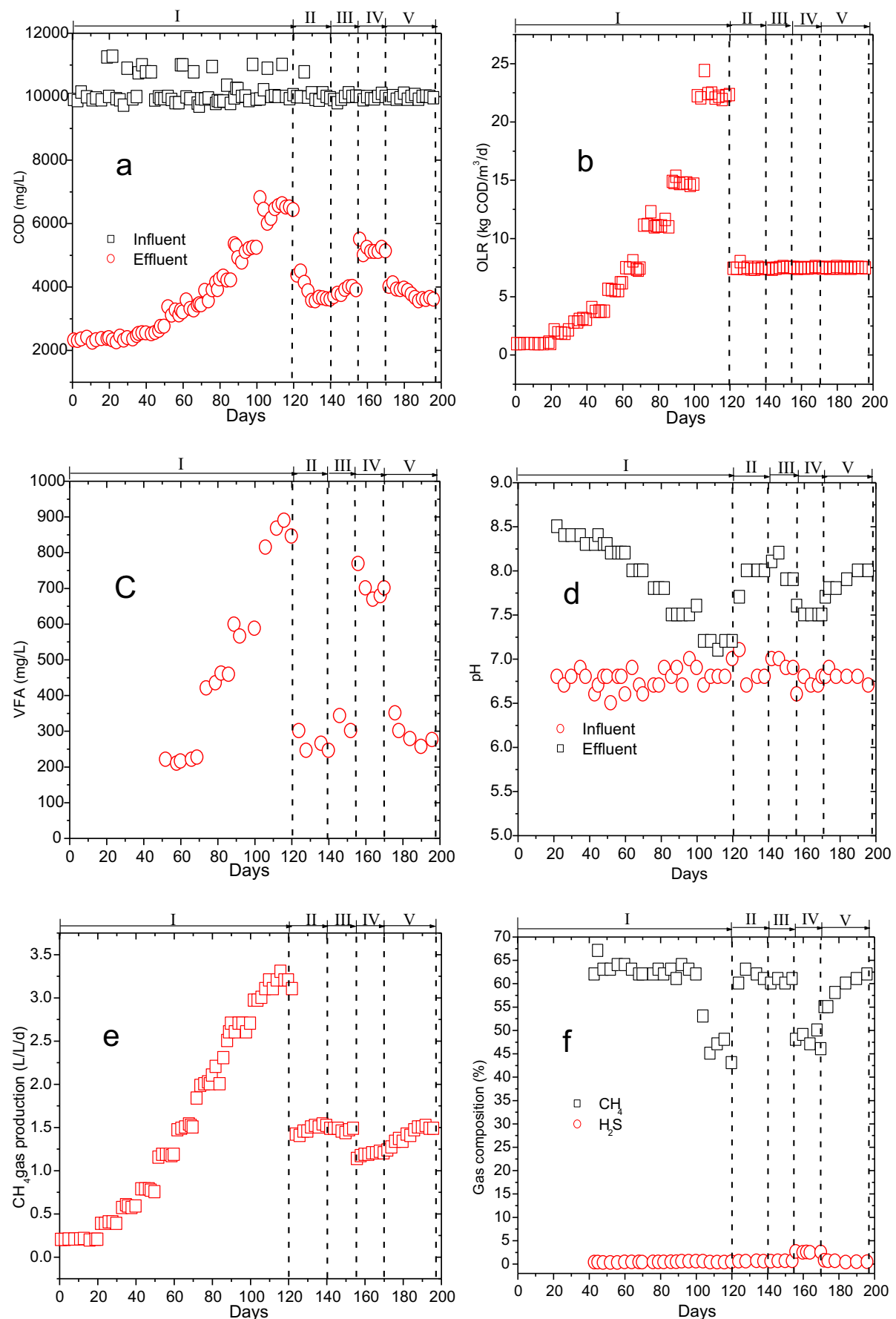

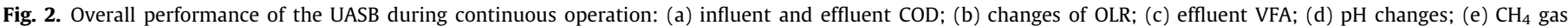
production rate and (f) gas compositions.

\subsection{Effect of OLR on variations of sulfur related species (Phases I and II)}

As shown in Fig. 3a and b, the effluent sulfate concentration was higher than the influent sulfate and increased significantly in spite of the generation of sulfide. This can be clearly attributed to the release of sulfate from organic sulfur compounds since the concentration of organic $S$ decreased significantly from approximately $1500 \mathrm{mg} \mathrm{SO}_{4}^{2-}-\mathrm{S} / \mathrm{L}$ to $300 \mathrm{mg} \mathrm{SO}{ }_{4}^{2}-\mathrm{S} / \mathrm{L}$ during the treatment (Fig. 3d). It should be noted that the increase of OLR from 12 to $24 \mathrm{COD} / \mathrm{m}^{3} / \mathrm{d}$ did not affect the release of sulfate, but affected the reduction of sulfate, suggesting that sulfur release could occur under acidified conditions. On the other hand, the variations of free and dissolved sulfide should be related with the changes of $\mathrm{pH}$.

\subsection{Effect of $\mathrm{COD} / \mathrm{SO}_{4}^{2-}$ on treatment performance (Periods III and IV)}

From day 140 to day 170 , the $\mathrm{COD} / \mathrm{SO}_{4}^{2-}$ ratio was decreased from 8 to 5 and then 1.5 by increasing the sulfate concentration from 1.25 to 2.0 and then $6.5 \mathrm{~g} / \mathrm{L}$. As shown in Fig. 2a, c and e, the treatment performance in terms of COD removal, VFA formation and methane production was not perceptibly affected by the decrease of the $\mathrm{COD} / \mathrm{SO}_{4}^{2-}$ ratio from 8 to 5 . At the same time, 

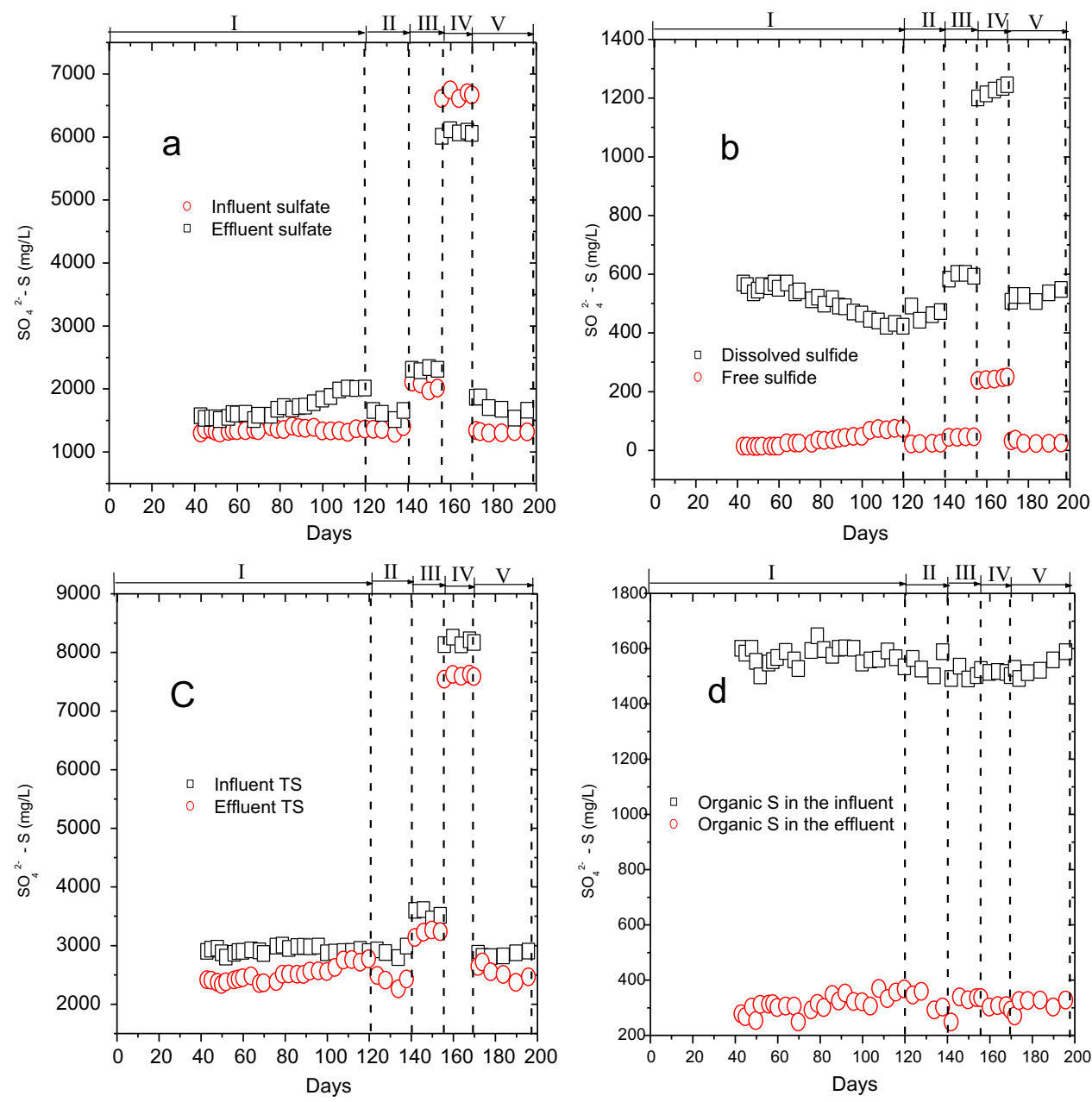

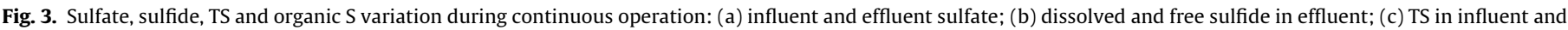
effluent and (d) organic S in influent and effluent.

formation of sulfide was not affected, either, as shown in Fig. 3b. However, when the $\mathrm{COD} / \mathrm{SO}_{4}^{2-}$ was further decreased to 1.5 , a decrease in COD removal (from $64 \%$ to $54 \%$ ) and methane content (from over $60 \%$ to around $50 \%$ ), and an increase of VFA production (from 300 to $680 \mathrm{mg} / \mathrm{L}$ ) were observed, together with a drop of methane production rate from $1.5 \mathrm{~L} / \mathrm{L} / \mathrm{d}$ to $1.2 \mathrm{~L} / \mathrm{L} / \mathrm{d}$ (Fig. $2 \mathrm{a}, \mathrm{c}$ and e). At the same time, significant increases in sulfide (dissolved and free sulfide, over $1200 \mathrm{SO}_{4}^{2}-\mathrm{S}$ and $240 \mathrm{SO}_{4}^{2}-\mathrm{S} \mathrm{mg} / \mathrm{L}$, respectively, in comparison with $600 \mathrm{SO}_{4}^{2}-\mathrm{S}$ and $40 \mathrm{SO}_{4}^{2}-\mathrm{S} \mathrm{mg/L}$ ) and $\mathrm{H}_{2} \mathrm{~S}$ gas ( $3 \%$ in comparison with $0.26 \%$ ) were observed (Figs. $2 \mathrm{f}$ and $3 \mathrm{~b}$ ), indicating the enhanced sulfate reduction activity. However, it is interesting that the release of sulfur from organic sulfur compounds was almost unaffected by the sudden increase in sulfur concentration. Thus it was concluded that the decomposition of the organic S compounds was not inhibited by the enhanced sulfate reduction activities.

When the $\mathrm{COD} / \mathrm{SO}_{4}^{2-}$ was set back to 8 on day 171 , however, the reactor exhibited a quick recovery, as shown in Figs. 2 and 3. The treatment performance in terms of COD removal and methane production almost returned to the original state (Phase II) within 15 days of operation.

\subsection{Microbial community structure analysis}

Two archaeal clone libraries and two bacterial ones were established for the biological samples taken on days 60 and 120 , respectively. In total, 48 archaeal clones were acquired in each of the two samples containing 26 and 29 operational taxonomic units (OTUs) respectively. As shown in Fig. 4, Methanobacterium sp., a hydrogentophic methanogen, was dominant, accounting for $54 \%$ of total clones of day 60 (OLR, $\left.6 \mathrm{~kg} \mathrm{COD} / \mathrm{m}^{3} / \mathrm{d}\right)$ followed by aceticlastic methanogens (38\%) including Methanosaeta concilii GP6 (23\%), Methanosaeta harundinacea (9\%) and Methanosarcina mazei (6\%). For the day 120 clone library (OLR, $24 \mathrm{~kg} \mathrm{COD} / \mathrm{m}^{3} / \mathrm{d}$ ), on the other hand, the aceticlastic methanogens including $M$. concilii GP6 (31\%), M. harundinacea (2\%) and M. mazei (21\%) accounted for $54 \%$ of the total clones, seconded with the hydrogentophic methanogen Methanobacterium sp (27\%) (Fig. 4).

At total of 111 and 117 bacterial clones were acquired in for the two samples, with 44 and 58 OTUs in each respectively. As shown in Table 3 , the bacterial clone library of day 60 was dominated by the clones affiliated with the phylum Firmicutes (67.5\%) followed by the phylum Proteobacteria (10.8\%) and phylum Chloroflexi (9\%). The Lysinibacillus sphaericus-like OTU was the single largest group (36\%) followed by the Ignavibacterium album one (13.5\%, though with a low similarity of $85 \%)$. For the library of day 120 presented in Table 4, however, the phyla Firmicutes (24.8\%) and Proteobacteria (23.2\%) became the two largest groups, followed by the phyla Chloroflexi (7.7\%), Bacteroidetes (11.9\%) and Candidate division (12\%) and Thermotogae (11.2\%). The distribution of the clones became much more even in comparison with that in the clone library of day 60 . 


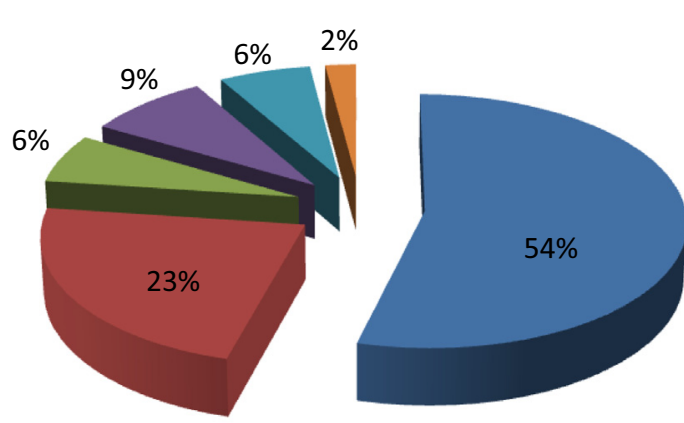

Methanobacterium sp. AL-21

Methanosaeta concilii GP6

chromosome

Methanosarcina mazei Go1

chromosome

- Methanosaeta harundinacea

6 Ac chromosome

Aciduliprofundum sp.

MAR08-339

- Candidatus Nitrososphaera

gargensis Ga9.2 chromosome

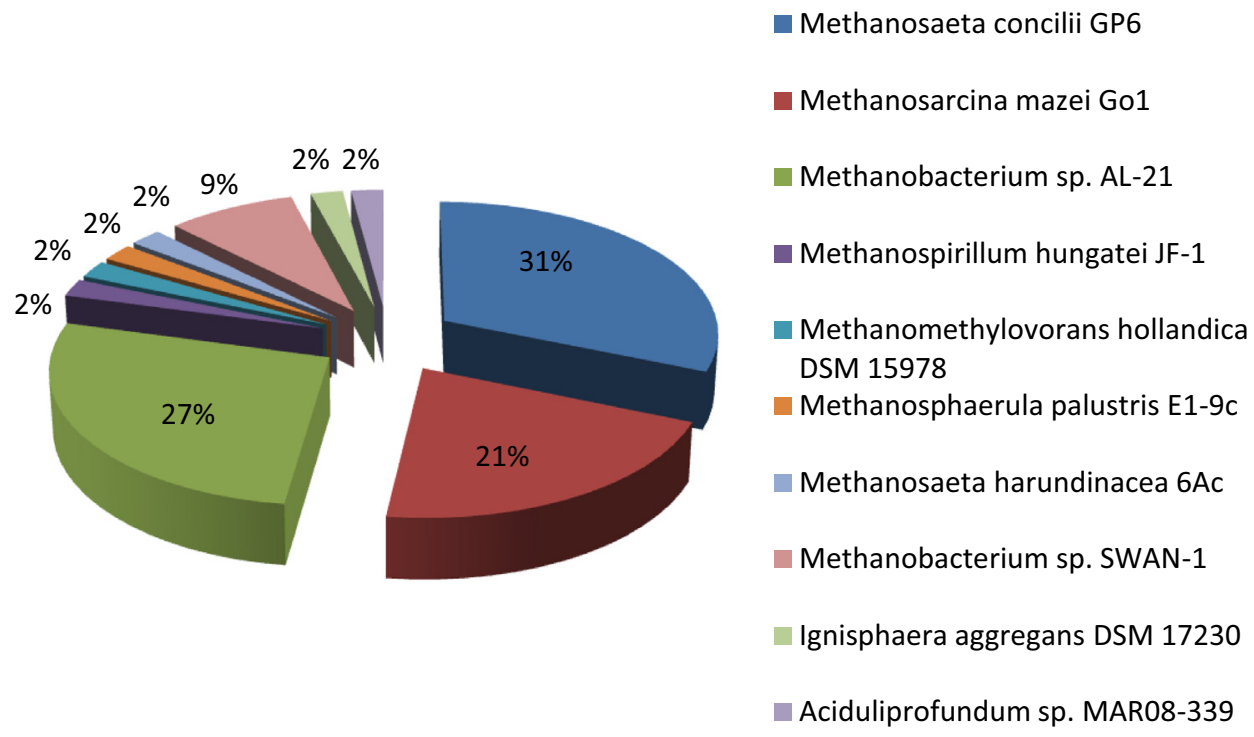

Fig. 4. Archaeal on days 60 and 120 .

\section{Discussion}

4.1. Effect of high concentrations of inorganic and organic sulfur on UASB performance

It has long been known that the presence of high concentration of sulfate could stimulate the growth of sulfate reducing bacteria (SRB) to out-compete methane producing bacteria (MPB) for substrates, and even to inhibit the growth of MPB through the production of sulfide $[24,25]$. So great efforts have been devoted to the development of strategies to control the substrate competition inhibition and the sulfide toxicity, such as sulfide precipitation using iron salts [19,26], gas stripping [27] and oxygenation [28]. In recent 10 years, some novel processes have been developed to alleviate the toxicity of sulfide to anaerobic treatment. Molybdate was investigated because molybdate is both a SRB inhibitor and a nutrient for methanogens [29]. Zero-valent iron (ZVI) serving can sever as an electron donor and be successfully used to alleviate the competition for substrates between SRB and MPB [30]. Microbial Fuel Cells (MFC) using graphite rods as electrodes provided a new approach for simultaneous anaerobic sulfide and nitrate removal coupled with electricity generation [31].

Though effective to some extent, all of these measures would increase the investment, and in some cases, may lead to other new problems. As a matter of fact, a chemical synthesis-based pharmaceutical production process generally generates many different waste streams, which may allow us to select suitable waste streams for anaerobic treatment. So the most important thing is to understand the conditions causing methanogenic inhibitions. COD/ $\mathrm{SO}_{4}^{2-}(\mathrm{S})$ ratio in influent is an important parameter affecting the competition between SRB and the other anaerobic bacteria and consequently significantly influences the performance of the anaerobic system [32]. A COD/S ratio higher than 10 (COD/ $\mathrm{SO}_{4}^{2-}>3.3$ ) is a threshold to prevent the sulfide from poisoning 
Table 3

Bacterial composition of granular sludge on day 60 .

\begin{tabular}{|c|c|c|c|c|c|}
\hline Plylum & Philogenetic group & OTUs & No. of clones & Percentage $(\%)$ & Similarity (\%) \\
\hline \multirow[t]{13}{*}{ Firmicutes } & Lysinibacillus sphaericus & 2 & 36 & 32.4 & 96 \\
\hline & Bacillus megaterium (WSH) & 2 & 2 & 1.8 & 87 \\
\hline & Bacillus megaterium (DSM) & 2 & 2 & 1.8 & 95 \\
\hline & Solibacillus silvestris & 1 & 1 & 0.9 & 91 \\
\hline & Clostridium cellulovorans & 1 & 4 & 3.6 & 94 \\
\hline & Clostridium clariflavum & 1 & 1 & 0.9 & 87 \\
\hline & Eubacterium limosum & 2 & 3 & 2.7 & 92 \\
\hline & Acetobacterium woodii & 2 & 4 & 3.6 & 99 \\
\hline & Pelotomaculum thermopropionicum & 1 & 1 & 0.9 & 87 \\
\hline & Ignavibacterium album & 1 & 15 & 13.5 & 85 \\
\hline & Syntrophothermus lipocalidus & 1 & 1 & 0.9 & 87 \\
\hline & Syntrophomonas wolfei subsp. & 2 & 2 & 1.8 & 93 \\
\hline & Moorella thermoacetica & 3 & 3 & 2.7 & 88 \\
\hline \multirow[t]{7}{*}{ Proteobacteria } & Desulfobacca acetoxidans & 1 & 2 & 1.8 & 95 \\
\hline & Syntrophus aciditrophicus & 2 & 3 & 2.7 & 98 \\
\hline & Syntrophobacter fumaroxidans & 1 & 3 & 2.7 & 95 \\
\hline & Geobacter uraniireducens & 1 & 1 & 0.9 & 97 \\
\hline & Lawsonia intracellularis & 1 & 1 & 0.9 & 83 \\
\hline & Aminobacterium colombiense & 1 & 1 & 0.9 & 91 \\
\hline & Acinetobacter baumannii & 1 & 1 & 0.9 & 98 \\
\hline \multirow[t]{2}{*}{ Caldiserica } & Solitalea canadensis & 1 & 1 & 0.9 & 81 \\
\hline & Owenweeksia hongkongensis & 1 & 1 & 0.9 & 82 \\
\hline \multirow[t]{2}{*}{ Chloroflexi } & Anaerolinea thermophila & 4 & 7 & 6.3 & 88 \\
\hline & Caldilinea aerophila & 1 & 3 & 2.7 & 85 \\
\hline \multirow[t]{2}{*}{ Actinobacteria } & Conexibacter woesei & 1 & 2 & 1.8 & 89 \\
\hline & Rubrobacter xylanophilus & 1 & 2 & 1.8 & 84 \\
\hline Bacteroidetes & Owenweeksia hongkongensis & 3 & 3 & 2.7 & 87 \\
\hline Thermotogae & Mesotoga prima & 1 & 3 & 2.7 & 98 \\
\hline Synergistetes & Moorella thermoacetica & 1 & 1 & 0.9 & 89 \\
\hline \multirow[t]{2}{*}{ Spirochaetes } & Spirochaeta caldaria & 1 & 1 & 0.9 & 89 \\
\hline & & 44 & 111 & 100 & \\
\hline
\end{tabular}

methanogens and avoids the failure of the anaerobic process $[9,10]$. However, a exception was reported by a recent study that though a $\mathrm{COD} / \mathrm{SO}_{4}^{2}$ ratio was as high as 5 , anaerobic rector in digesting high strength and sulfate rich vinasse eventually failed due to the toxicity of $\mathrm{H}_{2} \mathrm{~S}$ (free form of sulfide) on methanogens and SRBs [33]. Another exception was given in another recent study that though $\mathrm{COD} / \mathrm{SO}_{4}^{2-}$ ratio was as below as $1(\mathrm{COD} / \mathrm{S}=3)$, a UASB can remove $80 \%$ of COD and $30 \%$ of sulfate with HRT above $6 \mathrm{~h}$ and OLR below $12.3 \mathrm{~g} \mathrm{COD} / \mathrm{L} / \mathrm{d}$ in treating sulfate-rich wastewater containing ethanol and acetate [34]. Thus, the inhibition to various trophic groups by sulfide generated must be complex due to the variations in wastewater, seed sludge and operating conditions. However, to date, little has been done to investigate the impacts of the released sulfate from the organic sulfur compounds on methanogenic activities.

In this study, we have demonstrated that the methanogenic activities would not be affected by the presence of sulfate under a $\mathrm{COD} / \mathrm{SO}_{4}^{2-}$ of 5 , or a $\mathrm{COD} / \mathrm{S}$ of 15 , even when abundant organic sulfur compounds existed. Under a $\mathrm{COD} / \mathrm{SO}_{4}^{2-}$ of 8 , the methane production rate increased linearly from $0.2 \mathrm{~L} / \mathrm{L} /$ day to $2.7 \mathrm{~L} / \mathrm{L} /$ day with the increase of the OLR from 1 to $16 \mathrm{~kg} \mathrm{COD} / \mathrm{m}^{3} / \mathrm{d}$ (Fig. $2 \mathrm{~b}$ and e), though the COD removal rate decreased from $78 \%$ to approximately $50 \%$ (Fig. 2 a). However, no obvious change in methane yield rate was found when the OLR was further adjusted to $24 \mathrm{~kg} \mathrm{COD} / \mathrm{m}^{3} / \mathrm{d}$. This can be further explained by COD balance as the function of OLRs represented (Data not shown) that at OLR of $16 \mathrm{~kg} \mathrm{COD} / \mathrm{m}^{3} / \mathrm{d}$, the proportion for COD consumed for methane yield was round $41.5 \%$ whereas the proportion sharply reduced to $31.5 \%$ at OLR of $24 \mathrm{~kg} \mathrm{COD} / \mathrm{m}^{3} / \mathrm{d}$ (Fig. $2 \mathrm{~b}$ and e). In parallel, the COD removal rate reduced sharply from approximately $50 \%$ to $35 \%$, reflecting the decrease of COD rate efficiency was mainly due to the accumulation of VFA (Fig. 2c). Moreover, it should be noted that sulfate release from the organic S compounds was not affected perceptibly even when the reactor was under the acidification state at the OLR of $24 \mathrm{~kg} \mathrm{COD} / \mathrm{m}^{3} /$ day.

A further decrease of the $\mathrm{COD} / \mathrm{SO}_{4}^{2-}$ to 1.5 (or to 4.5 as $\mathrm{COD} / \mathrm{S}$ ) resulted in a decreases in COD removal (from 64\% to 54\%) and methane production rate (from $1.5 \mathrm{~L} / \mathrm{L} / \mathrm{d}$ to $1.2 \mathrm{~L} / \mathrm{L} / \mathrm{d}$ ), which should be caused by the competition of sulfate reduction activities since a significant increase in sulfide production (up to $1212 \mathrm{SO}_{4}^{2}-$ $\mathrm{S} \mathrm{mg} / \mathrm{L}$ ) was observed (Figs. 2a, b, e and 3a and b). Even under such a condition, however, sulfate release from organic sulfur compounds was not affected, either. Considering many arguments regarding to threshold of sulfide concentration and free sulfide which can result in inhibition to various trophic groups in anaerobic digestion processes, it is difficult to compare this work to the data obtained in earlier research. Additionally, it should be noted that the inhibition of methanogenic activity was reversible, and the reactor performance could be recovered easily once the COD/ $\mathrm{SO}_{4}^{2-}$ was returned to the normal condition.

\subsection{Characteristics of microbial community structures}

As described above, the increase of OLR from $6 \mathrm{~kg}$ (day 60) to $24 \mathrm{~kg} \mathrm{COD} / \mathrm{m}^{3} / \mathrm{d}$ (day 120 ) resulted in significant changes in both the bacterial and archaeal community structures. The hydrogentophic Methanobacterium-like methanogen (54\%) dominated the archaeal clone library of day 60 , followed by the aceticlastic M. concilii GP6 (23\%), M. harundinacea (9\%) and M. mazei (6\%), while the aceticlastic M. concilii GP6 (31\%), M. harundinacea (2\%) and M. mazei (21\%) dominated the day 120 clone library (Fig. 4). Generally, Methanosaeta-related species are more competitive in systems with high acetate concentration [19]. Actually, the acetate concentration did increase from $138 \mathrm{mg} / \mathrm{L}$ to $610 \mathrm{mg} / \mathrm{L}$ when the 
Table 4

Bacterial composition of granular sludge on day 120 .

\begin{tabular}{|c|c|c|c|c|c|}
\hline Plylum & Philogenetic group & OTUs & No. of clones & Percentage (\%) & Similarity (\%) \\
\hline \multirow[t]{10}{*}{ Firmicutes } & Eubacterium limosum & 3 & 9 & 7.7 & 92 \\
\hline & Eubacterium rectale & 2 & 2 & 1.7 & 95 \\
\hline & Acetobacterium woodii & 3 & 6 & 5.1 & 99 \\
\hline & Desulfitobacterium dichloroeliminans & 1 & 1 & 0.9 & 88 \\
\hline & Thermincola potens & 1 & 1 & 0.9 & 92 \\
\hline & Filifactor alocis & 1 & 2 & 1.7 & 87 \\
\hline & Clostridium difficile & 2 & 2 & 1.7 & 90 \\
\hline & Syntrophomonas wolfei. subsp. & 1 & 2 & 1.7 & 91 \\
\hline & Clostridium acidurici & 1 & 2 & 1.7 & 94 \\
\hline & Moorella thermoacetica & 1 & 2 & 1.7 & 88 \\
\hline \multirow[t]{9}{*}{ Proteobacteria } & Desulfovibrio vulgaris str. & 1 & 1 & 0.9 & 84 \\
\hline & Desulfohalobium retbaense & 1 & 1 & 0.9 & 78 \\
\hline & Desulfobacca acetoxidans & 1 & 1 & 0.9 & 85 \\
\hline & Syntrophus aciditrophicus & 4 & 5 & 4.3 & 92 \\
\hline & Syntrophobacter fumaroxidans & 3 & 10 & 8.5 & 95 \\
\hline & Pseudomonas mendocina & 1 & 1 & 0.9 & 99 \\
\hline & Acinetobacter sp. & 1 & 2 & 1.7 & 97 \\
\hline & Nautilia profundicola & 1 & 2 & 1.7 & 78 \\
\hline & Lawsonia intracellularis & 1 & 4 & 3.4 & 84 \\
\hline \multirow[t]{2}{*}{ Bacteroidetes } & Solitalea canadensis & 2 & 10 & 8.5 & 87 \\
\hline & Owenweeksia hongkongensis & 3 & 4 & 3.4 & 88 \\
\hline \multirow[t]{2}{*}{ Chloroflexi } & Anaerolinea thermophila & 6 & 8 & 6.8 & 88 \\
\hline & Caldilinea aerophila & 1 & 1 & 0.9 & 85 \\
\hline Caldiserica & Caldisericum exile & 2 & 2 & 1.7 & 93 \\
\hline \multirow[t]{2}{*}{ Candidate division } & Candidatus Cloacamonas acidaminovorans & 1 & 2 & 1.7 & 93 \\
\hline & Candidatus Methylomirabilis oxyfera & 1 & 1 & 0.9 & 86 \\
\hline \multirow[t]{2}{*}{ Synergistetes } & Thermanaerovibrio acidaminovorans & 2 & 4 & 3.4 & 89 \\
\hline & Aminobacterium colombiense & 2 & 3 & 2.6 & 93 \\
\hline Ignavibacteria & Ignavibacterium album & 1 & 6 & 5.1 & 85 \\
\hline \multirow[t]{2}{*}{ Thermotogae } & Mesotoga prima & 3 & 12 & 10.3 & 98 \\
\hline & Moorella thermoacetica & 1 & 1 & 0.9 & 85 \\
\hline \multirow[t]{3}{*}{ Actinobacteria } & Rubrobacter xylanophilus & 1 & 2 & 1.7 & 84 \\
\hline & Conexibacter woesei & 2 & 5 & 4.3 & 89 \\
\hline & & 58 & 117 & 100 & \\
\hline
\end{tabular}

OLR was increased from $6 \mathrm{~kg}$ to $24 \mathrm{~kg} \mathrm{COD} / \mathrm{m}^{3} / \mathrm{d}$ (Data not shown). Thus the shift from the hydrogentophic methanogens to the aceticlastic ones may be attributed to the changes in acetate concentrations. Of course, other factors, such as the concentrations of nutrients, micronutrients and the hydraulic load, may also play a role in the selection of Methanosaeta and Methanosarcina [35].

In comparison with the archaeal community structures, the changes in the bacterial community structures were more significant. As shown in Table 3, the bacterial clone library of day 60 was highly dominated with the clones affiliated with the phylum Firmicutes (67.5\%), with the L. sphaericus-like OTU as the largest single group (36\%). A recent work [36] revealed that a novel strain L. sphaericus DMT-7 could serve as model system for the efficient biodesulfurization of diesel and petrol. Another dichloromethane (DCM)-degrading organism L. sphaericus strain wh22 which can be isolated from pharmaceutical wastewater sludge was reported by $\mathrm{Wu}$ et al. [37]. Given the good performance in COD removal and sulfur release from the organic sulfur compounds at the OLR of $6 \mathrm{~kg} \mathrm{COD} / \mathrm{m}^{3} / \mathrm{d}$, it is reasonable to speculate that this L. sphaericus-like organism may have played an important role in organic matter degradation, particularly the decomposition of organic sulfur compounds. It is interesting that the presence of normal SRBs, such as Desulfobacca acetoxidans, was not very impressive ( $1.8 \%$ of total clones, as presented in Table 3 ), which might explain why the sulfate reduction did not proceed very well, as indicated by the relatively low sulfide concentrations.

For the library of day 120 , as described in Table 4, however, the high dominance of phylum Firmicutes (24.8\%) disappeared, with the increased presence of other groups including Proteobacteria
(23.2\%), Bacteroidetes (11.9\%) and Candidate division (12\%) and Thermotogae (11.2\%). It should be noted that the important L. sphaericus-like organism was not found in this clone library. As described previously, the sulfur release performance of the reactor did not change perceptibly, so the reason for the disappearance of this microbe was not clear. On the other hand, an OUT sharing 95\% sequence similarity with Syntrophobacter fumaroxidans accounted for $8.5 \%$ of the clones in library day 120 . Syntrophobacter species, such as S. fumaroxidans, Syntrophobacter pfennigii and Syntrophobacter wolinii have been described as syntrophic propionate - oxidizing bacterial species, and are closely related to the mesophilic sulfate reducers for propionate oxidation and some other organic compounds as well as hydrogen [38]. The appearance of this microbe might be related to the increase of the propionate concentration from $12 \mathrm{mg} / \mathrm{L}$ on day 60 to $98 \mathrm{mg} / \mathrm{L}$ on day 120 . Mesotoga, which shared a $98 \%$ sequence similarity with prima accounted for $10.3 \%$ of the clones on day 120 , almost three times as many as were noted on day 60 (Tables 3 and 4). Recent molecular studies have revealed the presence of "Mesotoga" in microbial communities degrading aromatic pollutants under anaerobic conditions [39]. Similarly, the appearance of Desulfovibrio-like SRB (84\% sequences similarity to vulgaris) after day 60 resulted from more hydrogen or sulfur being generated along with a simultaneous increase of OLR and SLR in the reactor (Table 4). The increased VFA concentration did not stimulate the growth rate of Desulfovibrio species because most Desulfovibrio species have been shown not to grow in the presence of VFA [40]. As such, the appearance of Desulfovibrio species is most likely attributed to the biodegradation of organic pollutants. The appearances of Clostridium cellulovorans, Clostridium 
acidurici, etc were identified during the sampling period (Tables 3 and 4). As described by Chien [41], Clostridium beijerinckii strain EV4 was observed to desulfonate alkyl-and arylsulfonate. Therefore, it can be postulated that some species from Clostridium genus played certain role in the release of sulfur from the p-acetylsulfanilyl chloride and para-ester and other unknown solfonated aromatics in the reactor.

\section{Conclusion}

A UASB operating under a continuous mode achieved satisfactory organic matter removal efficiency at a higher OLR of up to $8 \mathrm{~kg} \mathrm{COD} / \mathrm{m}^{3} / \mathrm{d}$ with the HRT of 1.3 day in treating high strength pharmaceutical wastewater in the presence of rich organic sulfur compounds and sulfate. The sulfate generated by the degradation of organic sulfur compounds had the undesirable effect of increasing the sulfate loading rate of the digester. A significant variation in the bacterial and archaeal community composition of sludge was observed when the reactor was feed from the initial OLR of $1 \mathrm{~kg}$ $\mathrm{COD} / \mathrm{m}^{3} / \mathrm{d}$ up to $24 \mathrm{~kg} \mathrm{COD} / \mathrm{m}^{3} / \mathrm{d}$ (day 120 ). The $\mathrm{COD} / \mathrm{SO}_{4}^{2-}$ ratio appears to have influenced the syntrophic and competitive relationships between sulfate-reducing and methane-producing organisms. No toxicity effects on sulfate-reducing bacteria were found, even at sulfide concentration as high as $1212 \mathrm{SO}_{4}^{2}-\mathrm{S} \mathrm{mg} /$ L. However, the methane-producing microorganisms may have been slightly inhibited at this sulfide concentration. The system can be $95 \%$ recovered by resetting the $\mathrm{COD} / \mathrm{SO}_{4}^{2-}$ ratio to 8 again within 15 days of operation.

\section{Acknowledgments}

This study was supported by the Ministry of Science and Technology, the People's Republic of China (2012AA063401, 2013DFG50150), NSFC 51178449 and Japan Society for the Promotion of Science (JSPS 2012-2015) (CAS-11209). We wish to thank the anonymous reviews and editors for their valuable suggestions on revising and improving the work.

\section{References}

[1] K. Perei, G. Rákhely, K.L. Kovács, Biodegradation of sulfanilic acid by Pseudomonas paucimobilis, Appl. Microbiol. Biotechnol. 55 (2001) 101-107.

[2] H. Tsuno, M. Kawamura, Development of an expanded-bed GAC reactor for anaerobic treatment of terephthalate-containing wastewater, Water Res. 43 (2009) 417-422.

[3] G.D. Sprott, G.G. Patel, Ammonia toxicity in pure cultures of methanogenic bacteria, Syst. Appl. Microbiol. 7 (1986) 358-363.

[4] J. Weijma, E.A.A. Bots, G. Tandlinger, A.J.M. Stams, L.M. Hulshoff Pol, G. Lettinga, Optimization of sulphate reduction in a methanol-fed thermophilic bioreactor, Water Res. 36 (2002) 1825-1833.

[5] P. Gilles, B. Nicolas, M. Rene, Start-up of anaerobic digestion of sulfate wastewater, Bioresour. Technol. 61 (1997) 21-27.

[6] J.P. Maree, W.F. Strydom, Biological sulfate removal in an up-flow packed bed reactor, Water Res. 19 (1985) 1101-1106.

[7] I.W. Koster, A. Rinzema, A.L. De Vegt, G. Lettinga, Sulfide inhibition of the methanogenic activity of granular sludge at various pH-levels, Water Res. 20 (1986) 1561-1567.

[8] A.W. Lawrence, P.L. Mccarty, The effects of sulfide on anaerobic treatment, Int J. Air Water Pollut. 10 (1966) 207-221.

[9] G.F. Parkin, N.A. Lynch, W. Kuo, E.L. Van Keuren, S.K. Bhattacharya, Interaction between sulfate reducers and methanogens fed acetate and propionate, Res. J. WPCF 62 (1990) 780-788.

[10] V.A. Vavilin, V.B. Vasiliev, S.V. Rytov, A.V. Ponomarev, Self-oscillating coexistence of methanogens and sulphate-reducers under hydrogen sulfide inhibition and the pH-regulating effect, Bioresour. Technol. 49 (1994) 105 119.

[11] C.A. Luckhurst, I. Millichip, B. Parker, J. Reuberson, M. Furber, A convenient synthesis of sulfonylureas from carboxylic acids and sulfomides via an in situ Curtius rearrangement, Tetrahedron Lett. 48 (2007) 8878-8882.

[12] A.S. Mogensen, B.K. Ahring, Formation of metabolites during biodegradation of linear alkylbenzene sulfonate in an upflow anaerobic sludge bed reactor under thermophilic conditions, Biotechnol. Bioeng. 77 (2002) 483-488.
[13] D.T. Sponza, P. Demirden, Treatability of sulfamerazine in sequential upflow anaerobic sludge blanket reactor (UASB)/completely stirred tank reactor (UASB)/completely stirred tank reactor (CSTR) processes, Sep. Purif. Technol. 56 (2007) 108-117.

[14] T.W. Federle, B.S. Schwab, Mineralization of surfactants in anaerobic sediments of a Laundromat waste-water pond, Water Res. 26 (1992) $123-127$.

[15] T.P. Delforno, D.Y. Okada, J. Polizel, I.K. Sakamoto, M.B.A. Varesche, Microbial characterization and removal of anionic surfactant in an expanded granular sludge bed reactor, Bioresour. Technol. 107 (2012) 103-109.

[16] L.L. de Oliveira, I.C.S. Duarte, I.K. Sakamoto, M.B.A. Varesche, Influence of support material on the immobilization of biomass for the degradation of linear alkylbenzene sulfonate in anaerobic reactors, J. Environ. Manage. 90 (2009) 1261-1268

[17] K. Denger, M.A. Kertesa, E.H. Vock, R. Schon, A. Magli, A.M. Cook, Anaerobic desulfonation of 4-tolylsulfonate and 2-(4-sulfophenyl) butyrate by a Clostridium sp, Appl. Environ. Microbiol. 62 (1996) 1526-1530.

[18] APHA, Standard Methods for Examination of Water and Wastewater, 20th ed., American Public Association, New York, 1998.

[19] R.E. Speece, Anaerobic Biotechnology For Industrial Wastewaters, Archae Press, Nashville, 1996.

[20] W.G. Weisburg, S.M. Barns, D.A. Pelletier, D.J. Lane, 16S ribosomal DNA amplification for phylogenetic study, J. Bacteriol. 173 (1991) 697-703.

[21] R.I. Amann, B.J. Binder, R.J. Olson, S.W. Chisholm, R. Devereux, D.A. Stahl, Combination of $16 \mathrm{~S}$ rRNA-targeted oligonucleotide probes with flow cytometry for analyzing mixed microbial populations, Appl. Environ. Microbiol. 56 (1990) 1919-1925.

[22] R. Grosskopf, P.H. Janssen, W. Liesack, Diversity and structure of the methanogenic community in anoxic rice paddy soil microcosms as examined by cultivation and direct 16S rRNA gene sequence retrieval, Appl. Environ. Microbiol. 64 (1998) 960-969.

[23] Y. Yu, C. Lee, J. Kim, S. Hwang, Group-specific primer and probes sets to detect methanogenic communities using quantitative real-time polymerase chain reaction, Biotechnol. Bioeng. 89 (2005) 670-679.

[24] J.K. Kristjanson, P. Schonheit, R.K. Thauer, Different Ks values for hydrogen of methanogenic bacteria and sulfate reducing bacteria: an explanation for the apparent inhibition of methanogenesis by sulfate, Arch. Microbiol. 131 (1982) 278-282.

[25] P. SchÖnheit, J.K. Kristjansson, R.K. Thauer, Kinetic mechanism for the ability of sulfate reducers to out-compete methanogens for acetate, Arch. Microbiol. 132 (1982) 285-288.

[26] F. Bilek, S. Wagner, Long term performance of an AMD treatment bioreactor using chemolithoautotrophic sulfate reduction and ferrous iron precipitation under in situ groundwater conditions, Bioresour. Technol. 104 (2012) 221227.

[27] B.L. Hilton, Anaerobic treatment of high sulfate wastewater [D] (Ph.D. thesis), University of Manitoba, Manitoba, 1987.

[28] S.K. Khanal, J.C. Huang, Anaerobic treatment of high sulfate wastewater with oxygenation to control sulfide toxicity, J. Environ. Eng. 129 (2003) 104-111.

[29] H.M. Isa, G.K. Anderson, Molybdate inhibition of sulphate reduction in two phase anaerobic digestion, Process Biochem. 40 (2005) 2079-2089.

[30] J.X. Zhang, Y.B. Zhang, X. Quan, Y. Liu, X.L. An, S. Chen, H.M. Zhao, Bioaugmentation and functional partitioning in a zero valent iron-anaerobic reactor for sulfate-containing wastewater treatment, Chem. Eng. J. 174 (2011) 159-165.

[31] J. Cai, P. Zheng, J.Q. Zhang, Z.F. Xie, W. Li, P. Sun, Simultaneous anaerobic sulfide and nitrate removal coupled with electricity generation in microbial fuel cell, Bioresour. Technol. 129 (2013) 224-228.

[32] S.I.C. Lopes, X. Wang, M.I. Capela, M.I. Capela, P.N.I. Lens, Effect of COD/SO $\mathrm{SO}_{4}^{2}$ ratio and sulfide on thermophilic $\left(55^{\circ} \mathrm{C}\right)$ sulfate reduction during the acidification of sucrose at pH 6, Water Res. 41 (2007) 2379-2392.

[33] E.L. Barrer, H. Spanjer, O. Romero, E. Rosa, J. Dewulf, Characterization of the sulfate reduction process in the anaerobic digestion of a very high strength and sulfate rich vinasse, Chem. Eng. J. 248 (2014) 383-393.

[34] Z.Q. Jing, Y. Hu, Q.G. Niu, Y.Y. Liu, Y.Y. Li, X.C. Wang, UASB performance and electron competition between methane-producing archaea and sulfatereducing bacteria in treating sulfate-rich wastewater containing ethanol and acetate, Bioresour. Technol. 137 (2013) 349-357.

[35] C.F. Forster, Anaerobic upflow sludge blanket reactors: aspects of theirs microbiology and their chemistry, J. Biotechnol. 17 (1992) 221-232.

[36] A. Bahuguna, M.K. Lily, A. Munjal, R.N. Singh, K. Dangwal, Desulfurization of dibenzothiophene (DBT) by a novel strain Lysinibacillus sphareicus DMT-7 isolated from diesel contaminated soil, J. Environ. Sci. 23 (2011) 975-982.

[37] S.J. Wu, Z.H. Hu, L.L. Zhang, X. Yu, J.M. Chen, A novel dichloromethanedegrading Lysinibacillussphareicus strain wh22 and its degradative plasmid, Appl. Microbiol. Biotechnol. 82 (2009) 731-740.

[38] S.Y. Chen, X.L. Liu, X.Z. Dong, Syntrophobacter sulfatireducens sp. nov., a novel syntrophic, propionate-oxidizing bacterium isolated from UASB reactors, Int. J. Syst. Evol. Microbiol. 55 (2005) 1310-1324.

[39] W.B. Hania, R. Ghodbane, A. Postec, C. Brochier-Amanet, M. Hamdi, M.L. Fardeau, B. Ollivier, Cultivation of the first mesophilic representative ("mesotoga") within the order Thermotogales, Syst. Appl. Microbiol. 34 (2011) 581-585.

[40] L.L. Barton, Sulfate-Reducing Bacteria, Plenum Press, New York, 1995.

[41] C.C. Chien, Arylsulfonates as sole source of sulfur for Clostridium pasteuranium DSM 12136, J. Basic Microbiol. 45 (2005) 274-278. 